\title{
Fruit quality of Brazilian genotypes of feijoa at harvest and after storage
}

\author{
Cassandro Vidal Talamini do Amarante ${ }^{(1)}$, Alexandra Goede de Souza ${ }^{(1)}$, \\ Thalita Dal Toé Benincá( ${ }^{(1)}$ and Cristiano André Steffens ${ }^{(1)}$
}

\begin{abstract}
(1)Universidade do Estado de Santa Catarina, Centro de Ciências Agroveterinárias, Avenida Luiz de Camões, oo 2.090, Conta Dinheiro, CEP 88520-000 Lages, SC, Brazil. E-mail: cassandro.amarante@udesc.br, alexandra.goede@gmail.com, thalitabeninca@hotmail.com, cristiano.steffens@udesc.br
\end{abstract}

\begin{abstract}
The objective of this work was to evaluate the physicochemical attributes and vitamin C contents of fruits of five Brazilian genotypes of feijoa (Acca sellowiana), at harvest and after cold storage. The Alcântara, Mattos, Helena, and Nonante cultivars, as well as accession 2316, were studied. The assessed attributes were: fresh mass loss, titratable acidity, soluble solids contents, soluble solids contents/titratable acidity ratio, $\mathrm{pH}$, skin and flesh color, texture, and vitamin C contents (skin and flesh). After storage, there were reductions of $2.9 \%$ in soluble solids contents, of $32.2 \%$ in titratable acidity, and of approximately $85 \%$ in texture attributes, besides increases of $36.3 \%$ in the soluble solids contents/titratable acidity ratio and of $21.7 \%$ in the $\mathrm{pH}$ of fruits. The vitamin $\mathrm{C}$ content in the skin was higher than that in the flesh, and increased in both skin and flesh after storage. 'Alcântara' fruits have the highest contents of vitamin C in the skin and flesh. Fruits of 'Nonante' and 'Mattos' show better preservation of the texture attributes, and fruits of 'Nonante', the lowest levels of flesh browning during storage.
\end{abstract}

Index terms: Acca sellowiana, ascorbic acid, functional food, native fruit trees, natural antioxidant, postharvest, soluble solids content.

\section{Qualidade dos frutos de genótipos brasileiros de goiabeira- serrana na colheita e após o armazenamento}

Resumo - O objetivo deste trabalho foi avaliar os atributos físico-químicos e o conteúdo de vitamina $\mathrm{C}$ em frutos de cinco genótipos brasileiros de goiabeira-serrana (Acca sellowiana), na colheita e após o armazenamento refrigerado. Foram estudadas as cultivares Alcântara, Mattos, Helena e Nonante, e o acesso 2316. Avaliaram-se os atributos: perda de massa fresca, acidez titulável, teores de sólidos solúveis, relação sólidos solúveis/acidez titulável, $\mathrm{pH}$, coloração da casca e da polpa, textura e conteúdo de vitamina $\mathrm{C}$ (casca e polpa). Após o armazenamento, houve redução de 2,9\% nos teores de sólidos solúveis, de 32,2\% na acidez titulável e de aproximadamente $85 \%$ nos atributos de textura, além de aumentos de $36,3 \%$ na relação sólidos solúveis/acidez titulável e de $21,7 \%$ no $\mathrm{pH}$ dos frutos. O conteúdo de vitamina $\mathrm{C}$ na casca foi superior ao da polpa, e aumentou na casca e na polpa após o armazenamento. Frutos de 'Alcântara' apresentam os maiores conteúdos de vitamina $\mathrm{C}$ na casca e na polpa. Frutos de 'Nonante' e 'Mattos' apresentam melhor preservação dos atributos de textura, e frutos de 'Nonante', menor escurecimento de polpa durante o armazenamento.

Termos para indexação: Acca sellowiana, ácido ascórbico, alimento funcional, frutíferas nativas, antioxidante natural, pós-colheita, sólidos solúveis.

\section{Introduction}

Native fruit species have been attracting the attention of producers and the global consumer market, and feijoa Acca sellowiana (O.Berg.) Burret [Syn. Feijoa sellowiana (O.Berg.) O.Berg.] is an important representative of this group. This species belongs to the Myrtaceae family and is native to the Southern region of Brazil and to Uruguay (Schotsmans et al., 2011).

Feijoa trees grow mainly at altitudes higher than 800 $\mathrm{m}$, preferentially above $1,000 \mathrm{~m}$ (Moretto et al., 2014). In Southern Brazil, fruit maturation occurs between March and May (Santos et al., 2011). Physiological maturity is identified when the fruit naturally detaches from the tree, at which point it presents excellent taste 
and aroma characteristics (Schotsmans et al., 2011). Because it is physically similar to common guava, in Brazil, feijoa fruit is referred to as "goiaba-serrana", "goiaba-do-mato", and "goiaba-do-campo" (Moretto et al., 2014).

Feijoa fruits have antitumor (Bontempo et al., 2007), anti-inflammatory (Rossi et al., 2007), antioxidant (Ömer et al., 2010; Pasquariello et al., 2015), hepatoprotective (El-Shenawi et al., 2008; Karami et al., 2013), and gastroprotective (Monforte et al., 2014) action. These fruits also represent an important source of vitamin C (Belous et al., 2014; Monforte et al., 2014; Pasquariello et al., 2015) and minerals (RomeroRodriguez et al., 1994).

Feijoa fruits have significant economic value in several countries, including New Zealand, Colombia, and the USA (Schotsmans et al., 2011). In Brazil, notably in the state of Santa Catarina, the cultivation of feijoa is still restricted to small areas, but with prospects for expansion. The species has been studied in the state since 1986, and, in 2007 and 2008, the following four commercial cultivars were launched from there by Empresa de Pesquisa Agropecuária e Extensão Rural de Santa Catarina (Epagri): Alcântara, Mattos, Helena, and Nonante (Santos et al., 2011).

Knowledge of the postharvest physiology of fruits is of vital importance to provide technical support to extend the storage period, conserving physicochemical, organoleptic, and nutritional characteristics. As ripening progresses, feijoa fruits undergo physicochemical changes, such as weight loss, taste deterioration (associated with a reduction in titratable acidity and soluble solids contents), and rapid darkening of the flesh, resulting in serious limitations in meeting the demands of the fresh fruit market (Rodríguez et al., 2006; Schotsmans et al., 2011). The fruits can be stored after harvest for approximately three weeks, under refrigeration at $4^{\circ} \mathrm{C}$ (Velho et al., 2011; Amarante et al., 2013), before the organoleptic qualities are affected and the flesh begins to darken. This storage period is relatively short and, even though, in most cases, the fruit retains an external appearance appropriate for consumption, the flesh already shows signs of darkening and losses in taste and aroma.

The objective of this work was to evaluate the physicochemical attributes and vitamin $\mathrm{C}$ contents of fruits of five Brazilian genotypes of feijoa, at harvest and after cold storage.

\section{Materials and Methods}

Feijoa fruits were harvested from an orchard of the active germplasm bank of Epagri, at the experimental station located in the municipality of São Joaquim $\left(28^{\circ} 16^{\prime} 40^{\prime \prime} \mathrm{S}, 49^{\circ} 56^{\prime} 09^{\prime \prime} \mathrm{W}\right.$, at an altitude of $\left.1,400 \mathrm{~m}\right)$, in the state of Santa Catarina, Brazil. Fruits of the Alcântara, Helena, Mattos, and Nonante cultivars and of accession 2316 (with the potential to be launched as a cultivar) were harvested at the commercial maturity stage, when the fruits can be easily detached from the plant. Fruits were then immediately transported to the laboratory of postharvest physiology and technology at Universidade do Estado de Santa Catarina, in the municipality of Lages, also in the state of Santa Catarina, where the analyses were carried out.

In 2012, 2013, and 2014, fruits of the five genotypes were evaluated regarding physicochemical attributes, both at harvest and after 21 days of refrigerated storage at $4 \pm 1^{\circ} \mathrm{C}$ and $90 \pm 5 \%$ relative humidity $(\mathrm{RH})$, followed by two days under ambient conditions $\left(23 \pm 2^{\circ} \mathrm{C}\right.$ and $75 \pm 5 \% \mathrm{RH})$. The following fruit attributes were assessed: fresh mass loss, titratable acidity, soluble solids contents, soluble solids contents/titratable acidity ratio, $\mathrm{pH}$, skin (external epidermis and internal parenchyma) and flesh color, and texture (compression and penetration forces).

Fresh mass loss (\%) was evaluated by weighing the fruits at harvest (before storage) and after 21 days of refrigerated storage, followed by two days under ambient conditions (Antunes et al., 2003).

The titratable acidity values (percentage of citric acid) were obtained by titrating $10 \mathrm{~mL}$ of juice extracted from the fruit, diluted with $90 \mathrm{~mL}$ of distilled water, with $0.1 \mathrm{~N}$ sodium hydroxide, until $\mathrm{pH}$ 8.1, with the aid of the TitroLine Easy (SI Analytics, Mainz, Germany) automatic titration unit (Amarante et al., 2008). The $\mathrm{pH}$ of the juice was determined with the aid of the K39-2014B benchtop pH meter (Kasvi, Curitiba, PR, Brazil). The soluble solids content (\%) of the fruit juice was obtained using an Abbe digital refractometer model PR-201 alpha (Atago Co., Ltd., Tokyo, Japan), with automatic temperature compensation (Amarante et al., 2008).

The color of the skin (external epidermis and internal parenchyma) and flesh of the fruits was determined with the aid of the CR 400 colorimeter (Konica Minolta Inc., Tokyo, Japan) through the quantification of lightness (L), chroma (C), and hue angle $\left(\mathrm{h}^{\circ}\right)($ Amarante 
et al., 2008). For the color measurement of the external epidermis of the skin, two readings were taken from equidistant points along the equatorial portion of the fruit. To measure the color of the flesh, the fruits were cut in half and the reading was immediately taken from the central portion of the flesh. After the removal of the flesh with the aid of a spoon, the reading of the color of the internal parenchyma of the skin was also immediately taken.

Texture was analyzed with the aid of the TA.XT plus electronic texture analyzer (Stable Micro Systems Ltd., Surrey, United Kingdom), according to the methodology described by Amarante et al. (2008). For the quantification of the fruit penetration force, a 2-mm diameter probe (model PS2) was inserted into the equatorial portion of the fruits, and two readings were taken from opposite sides. The probe was introduced to a depth of $8 \mathrm{~mm}$, with pre-test, test, and post-test velocities of 10,1 , and $10 \mathrm{~mm} \mathrm{~s}^{-1}$, respectively. The force required for fruit compression (until achieving a 3-mm deformation of the fruit surface) was determined using a plunger (model $\mathrm{P} / 75$ ) with a diameter of $75 \mathrm{~mm}$, with pre-test, test, and post-test velocities of $10,0.5$, and 30 $\mathrm{mm} \mathrm{s}^{-1}$, respectively.

In 2013 and 2014, fruits of the five evaluated genotypes were analyzed with regard to the vitamin C contents (mg ascorbic acid per $100 \mathrm{~g}$ fresh weight) in the skin (external epidermis and internal parenchyma) and flesh tissues. Vitamin $\mathrm{C}$ was assessed at harvest and after 21 days of refrigerated storage $\left(4 \pm 1^{\circ} \mathrm{C}\right.$ and $90 \pm 5 \%$ $\mathrm{RH}$ ), followed by two days under ambient conditions $\left(23 \pm 2^{\circ} \mathrm{C}\right.$ and $\left.75 \pm 5 \% \mathrm{RH}\right)$ by the spectrophotometric method using 2,4-dinitrophenylhydrazine (Strohecker \& Henning, 1967). In 2014, the vitamin C contents were determined for the skin and flesh of fruits of the cultivar Alcântara, after 21 days of refrigerated storage $\left(4 \pm 1^{\circ} \mathrm{C}\right.$ and $\left.90 \pm 5 \% \mathrm{RH}\right)$, followed by exposure to ambient conditions $(0,6,12,24,36,48$, and 72 hours at $23 \pm 2{ }^{\circ} \mathrm{C}$ and $75 \pm 5 \% \mathrm{RH}$ ).

The experiment was carried out in a completely randomized design, with eight replicates of five fruits each. Since the data for all variables were consistent along the seasons (three seasons for the physicochemical attributes and two for vitamin $\mathrm{C}$ contents), only the average data for all seasons were subjected to the analysis of variance, and the means of the treatments were compared by Tukey's test, at $5 \%$ probability, using the SAS software (SAS Institute
Inc., Cary, NC, USA). For the data on the vitamin $\mathrm{C}$ contents in the skin and flesh of the fruits of the cultivar Alcântara, after refrigerated storage followed by exposure to ambient conditions, polynomial models were tested (linear and quadratic), relating the vitamin $\mathrm{C}$ content to the number of hours at ambient temperature (0 to 72 hours).

\section{Results and Discussion}

The average fresh mass of the fruits at harvest varied from $94.6 \mathrm{~g}$ for 'Nonante' to $120.5 \mathrm{~g}$ for 'Mattos' (Table 1). The fresh mass loss of the fruits during the 21 days of refrigerated storage, followed by two days under ambient conditions, did not differ between genotypes, with an average of $3.6 \%$. Of the total fresh mass loss, $28.4 \%$ occurred during the two days of fruit exposure to ambient conditions after removal from the refrigerated environment. The fresh mass loss observed in the post-refrigeration period, compared with that during total fruit storage time (23 days), shows the importance of refrigerated storage for this fruit. The lower temperature and the higher relative humidity conditions in refrigerated storage reduce the vapor pressure deficit and, consequently, decrease fruit transpiration, which contributes to the low fresh

Table 1. Fresh weight of fruits of different genotypes of feijoa (Acca sellowiana) at harvest and after 21 days of cold storage (CS, $4 \pm 1^{\circ} \mathrm{C}$ and $\left.90 \pm 5 \% \mathrm{RH}\right)$, followed by two days at ambient temperature (AT, $23 \pm 2^{\circ} \mathrm{C}$ and $75 \pm 5 \% \mathrm{RH}$ ), as well as total fresh weight loss ${ }^{(1)}$.

\begin{tabular}{|c|c|c|c|c|}
\hline \multirow[t]{2}{*}{ Genotype } & \multicolumn{3}{|c|}{ Fresh weight (grams per fruit) } & \multirow{2}{*}{$\begin{array}{c}\text { Total fresh } \\
\text { weight } \\
\text { loss }(\%)^{(2)}\end{array}$} \\
\hline & At harvest & $\begin{array}{c}\text { After } 21 \\
\text { days of CS }\end{array}$ & $\begin{array}{l}\text { After two } \\
\text { days at AT }\end{array}$ & \\
\hline Alcântara & $109.9 \mathrm{a}$ & $107.0 \mathrm{a}$ & $104.9 \mathrm{a}$ & $4.5^{\mathrm{ns}}$ \\
\hline Helena & $118.9 \mathrm{a}$ & $115.5 \mathrm{a}$ & $114.7 \mathrm{a}$ & 3.5 \\
\hline Mattos & $120.5 \mathrm{a}$ & $118.4 \mathrm{a}$ & $117.6 \mathrm{a}$ & 2.4 \\
\hline Nonante & $94.6 \mathrm{~b}$ & $91.5 \mathrm{~b}$ & $90.7 b$ & 4.1 \\
\hline Accession 2316 & $118.5 \mathrm{a}$ & $115.6 \mathrm{a}$ & $114.1 \mathrm{a}$ & 3.7 \\
\hline Mean & 112.5 & 109.6 & 108.4 & 3.6 \\
\hline CV (\%) & 16.9 & 18.3 & 18.1 & 39.9 \\
\hline
\end{tabular}

${ }^{(1)}$ Means followed by equal letters, in the columns, do not differ by Tukey's test, at 5\% probability. ${ }^{(2)}$ Total fresh weight loss between harvest and cold storage for 21 days, followed by two additional days at ambient

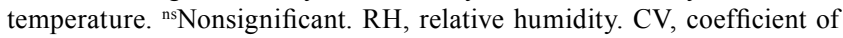
variation. Values are the mean of three years $(2012,2013$, and 2014). 
mass loss of the samples (Mélo et al., 2000; Antunes et al., 2003). In feijoa fruits harvested in New Zealand, Rupavatharam et al. (2015) reported an average fresh mass loss of $1.2 \%$ after six weeks of refrigerated storage at $4^{\circ} \mathrm{C}$ and $90 \% \mathrm{RH}$.

The average soluble solids content for the feijoa genotypes at harvest was $10.12 \%$. Fruits of the Mattos cultivar had the highest soluble solids contents at harvest and after refrigerated storage, followed by two days under ambient conditions. The Nonante and Helena cultivars, as well as accession 2316, had intermediate soluble solids contents, whereas the Alcântara cultivar had the lowest (Table 2).

After refrigerated storage, the soluble solids contents only reduced for accession 2316 an increased in Mattos cultivar, in comparison to the assessment at harvest. For the other genotypes, soluble solids contents did not change during cold storage. Similar results were obtained by Velho et al. (2011) for feijoa fruits harvested in São Joaquim, in the state of Santa Catarina - there was no reduction in the soluble solids contents after four weeks of refrigerated storage $\left(4^{\circ} \mathrm{C}\right.$ and $90 \% \mathrm{RH}$ ). However, feijoa fruits harvested in the same location showed a reduction in soluble solids contents after three weeks of refrigerated storage at $4^{\circ} \mathrm{C}$ and 90\% RH (Amarante et al., 2013).

At harvest, 'Alcântara' had the lowest titratable acidity values, and no differences were found between the other genotypes. After the storage period, the
Mattos and Nonante cultivars showed the highest titratable acidity values. Titratable acidity decreased during refrigerated storage, except in 'Mattos'. The average titratable acidity of the five genotypes decreased from $1.21 \%$ at harvest to $0.82 \%$ after storage, indicating a reduction of $32.2 \%$. This decrease in titratable acidity shows that organic acids represent an important substrate for respiration in feijoa fruits at postharvest (Amarante et al., 2013).

The $\mathrm{pH}$ of the fruits of the feijoa genotypes differed only at harvest, varying from 2.45 to 3.68 . These values are close to those reported by Romero-Rodriguez et al. (1994) for feijoa. After the storage period, the average $\mathrm{pH}$ value for the five feijoa genotypes was 3.68 , showing an increase of $21.7 \%$ in comparison with the corresponding value at harvest. This $\mathrm{pH}$ increase was mainly due to the reduction in titratable acidity observed in the fruits at the end of the storage period.

Considering the average values for the five genotypes, the soluble solids contents/titratable acidity ratio increased by $36.3 \%$ after 21 days of refrigerated storage, followed by two more days under ambient conditions (Table 2). This increase in the soluble solids content/titratable acidity ratio after storage is explained by the reduction in titratable acidity (Amarante et al., 2013). The soluble solids contents/ titratable acidity ratio was higher for the Alcântara cultivar and accession 2316 at harvest, and for the Helena and Alcântara cultivars after storage. It should

Table 2. Soluble solids contents (SSC), titratable acidity (TA), SSC/TA ratio, and pH of fruits of different genotypes of feijoa (Acca sellowiana) at harvest and after 21 days of cold storage $\left(4 \pm 1^{\circ} \mathrm{C}\right.$ and $\left.90 \pm 5 \% \mathrm{RH}\right)$, followed by two days at ambient temperature $\left(23 \pm 2^{\circ} \mathrm{C} \text { and } 75 \pm 5 \% \mathrm{RH}\right)^{(1)}$.

\begin{tabular}{|c|c|c|c|c|c|c|c|c|}
\hline \multirow[t]{2}{*}{ Genotype } & \multicolumn{2}{|c|}{ SSC (\%) } & \multicolumn{2}{|c|}{ TA (\%) } & \multicolumn{2}{|c|}{ SSC/TA ratio } & \multicolumn{2}{|c|}{$\mathrm{pH}$} \\
\hline & At harvest & $\begin{array}{l}\text { After cold } \\
\text { storage }\end{array}$ & At harvest & $\begin{array}{l}\text { After cold } \\
\text { storage }\end{array}$ & At harvest & $\begin{array}{l}\text { After cold } \\
\text { storage }\end{array}$ & At harvest & $\begin{array}{l}\text { After cold } \\
\text { storage }\end{array}$ \\
\hline Alcântara & $8.93 \mathrm{cA}$ & $8.60 \mathrm{cA}$ & $0.81 \mathrm{bA}$ & $0.55 \mathrm{cB}$ & $11.14 \mathrm{aB}$ & $15.92 \mathrm{abA}$ & $3.68 \mathrm{aB}$ & $4.02 \mathrm{aB}$ \\
\hline Helena & $9.87 \mathrm{bA}$ & $9.48 \mathrm{bA}$ & $1.19 \mathrm{aA}$ & $0.49 \mathrm{cB}$ & $8.30 \mathrm{bB}$ & $19.71 \mathrm{aA}$ & $2.45 \mathrm{cB}$ & $3.77 \mathrm{aA}$ \\
\hline Mattos & $11.16 \mathrm{aB}$ & $11.89 \mathrm{aA}$ & $1.46 \mathrm{aA}$ & $1.24 \mathrm{aA}$ & $8.22 \mathrm{bA}$ & $12.56 \mathrm{bcA}$ & $2.67 \mathrm{cB}$ & $3.49 \mathrm{aA}$ \\
\hline Nonante & $10.37 \mathrm{bA}$ & $9.95 \mathrm{bA}$ & $1.47 \mathrm{aA}$ & 1.11abB & $7.64 \mathrm{bA}$ & $9.16 \mathrm{cA}$ & $2.46 \mathrm{cB}$ & $3.54 \mathrm{aA}$ \\
\hline Accession 2316 & $10.31 \mathrm{bA}$ & $9.25 \mathrm{bcB}$ & $1.12 \mathrm{aA}$ & $0.73 \mathrm{bcB}$ & $9.20 \mathrm{abB}$ & $12.93 \mathrm{bcA}$ & $3.18 \mathrm{bB}$ & $3.60 \mathrm{aA}$ \\
\hline Mean & $10.12 \mathrm{~A}$ & $9.83 \mathrm{~B}$ & $1.21 \mathrm{~A}$ & $0.82 \mathrm{~B}$ & $8.95 \mathrm{~B}$ & $14.05 \mathrm{~A}$ & $2.88 \mathrm{~B}$ & $3.68 \mathrm{~A}$ \\
\hline Coefficient of variation (\%) & 8.2 & 12.9 & 29.8 & 51.1 & 22.6 & 35.1 & 18.3 & 11.9 \\
\hline
\end{tabular}

(1)Means followed by equal letters, lowercase in the columns comparing genotypes and uppercase in the lines comparing harvest and cold storage evaluations for the same attribute, do not differ by Tukey's test, at 5\% probability. Values are the mean of three years (2012, 2013, and 2014). RH, relative humidity. 
be noted that, for 'Helena', the soluble solids contents/ titratable acidity ratio increased from 8.30 at harvest to 19.71 after storage. This indicates that this genotype has a more rapid loss of postharvest sensorial quality than the other ones studied.

Regarding the textural analysis, considering the average values for all genotypes, the fruit compression and penetration forces reduced in 43.2 and 29.1\%, respectively, after storage (Table 3 ). This shows that the fruit texture deteriorates substantially as the fruit ripens (Rupavatharam et al., 2015). The Nonante cultivar had higher values for fruit penetration force at harvest and after storage than the other genotypes. At harvest, the Mattos cultivar showed the greatest fruit compression force, and no differences were found between the other genotypes. After storage, although the Mattos cultivar had the highest loss of firmness (49.5\%), it still showed, together with the Helena cultivar, the highest values for fruit compression force (Table 3). The texture data indicate that the Nonante and Mattos cultivars showed greater capacity to resist deformation, remaining in better conditions after refrigerated storage, followed by exposure to ambient temperature.

Table 3. Forces for penetration and compression of fruits of different genotypes of feijoa (Acca sellowiana) at harvest and after 21 days of cold storage $\left(4 \pm 1^{\circ} \mathrm{C}\right.$ and $\left.90 \pm 5 \% \mathrm{RH}\right)$, followed by two days at ambient temperature $\left(23 \pm 2^{\circ} \mathrm{C}\right.$ and $75 \pm 5 \% \mathrm{RH})^{(1)}$.

\begin{tabular}{lccccc}
\hline Genotype & \multicolumn{2}{c}{$\begin{array}{c}\text { Force for } \\
\text { penetration }(\mathrm{N})^{(2)}\end{array}$} & & \multicolumn{2}{c}{$\begin{array}{c}\text { Force for } \\
\text { compression }(\mathrm{N})\end{array}$} \\
\cline { 2 - 3 } \cline { 5 - 6 } & At harvest & $\begin{array}{c}\text { After } \\
\text { storage }\end{array}$ & & At harvest & $\begin{array}{c}\text { After } \\
\text { storage }\end{array}$ \\
\hline Alcântara & $7.71 \mathrm{bA}$ & $4.93 \mathrm{bB}$ & & $55.65 \mathrm{bA} *$ & $30.01 \mathrm{cB}$ \\
Helena & $6.29 \mathrm{cA}$ & $4.35 \mathrm{bB}$ & & $56.58 \mathrm{bA}$ & $36.68 \mathrm{abB}$ \\
Mattos & $6.20 \mathrm{cA}$ & $4.98 \mathrm{bB}$ & & $78.56 \mathrm{aA}$ & $39.56 \mathrm{aB}$ \\
Nonante & $11.01 \mathrm{aA}$ & $7.47 \mathrm{aB}$ & & $52.07 \mathrm{bA}$ & $34.44 \mathrm{bB}$ \\
Accession 2316 & $5.52 \mathrm{cA}$ & $4.30 \mathrm{bB}$ & & $50.42 \mathrm{bA}$ & $25.95 \mathrm{cB}$ \\
\hline Mean & $7.35 \mathrm{~A}$ & $5.21 \mathrm{~B}$ & & $58.22 \mathrm{~A}$ & $33.33 \mathrm{~B}$ \\
CV $(\%)$ & 30.6 & 26.2 & & 20.9 & 17.3 \\
\hline
\end{tabular}

${ }^{(1)}$ Means followed by equal letters, lowercase in the columns comparing genotypes and uppercase in the lines comparing harvest and cold storage evaluations for the same attribute, do not differ by Tukey's test, at 5\% probability. Values are the mean of three years $(2012,2013$, and 2014).

${ }^{(2)} \mathrm{N}$, Newton. RH, relative humidity. CV, coefficient of variation.
In relation to the external epidermis color, reductions in the $\mathrm{L}$ and $\mathrm{C}$ values were found after storage (Table 4). The results showed that there was a loss in the green color intensity, as well as in the shine of the external epidermis as fruit ripened. A reduction in the $\mathrm{L}$ values after storage was observed for the Alcântara, Helena, and Mattos cultivars. There was also a reduction in the $\mathrm{C}$ values (loss of color definition) in the Helena cultivar, and in $\mathrm{h}^{\mathrm{o}}$ (loss of green color intensity) in the Mattos cultivar after storage. However, it should be highlighted that all changes in the color of the external epidermis of feijoa fruits are practically imperceptible to the naked eye. Therefore, evaluating fruit quality based on color changes is not recommended when carried out by a subjective visual assessment, only when a colorimeter is used.

Storage favored the darkening of the internal parenchyma of the skin and flesh (lowest $L$ value). The $\mathrm{L}$ value reduced in the internal parenchyma of the skin of the Alcântara and Nonante cultivars, and in the flesh of the Mattos cultivar and accession 2316. The flesh darkening of feijoa fruits after refrigerated storage $\left(4^{\circ} \mathrm{C}\right)$ for 21 days, followed by ambient temperature $\left(23^{\circ} \mathrm{C}\right)$ for two days, has also been previously reported by Amarante et al. (2013). Internal darkening, particularly in the flesh, adversely affects the quality of fruit destined for consumption. The results indicate that the Mattos cultivar and accession 2316 were more sensitive to flesh darkening at postharvest. The fruits of the Nonante cultivar did not show changes in any of the flesh color attributes during storage, indicating their better postharvest potential due to lower flesh darkening.

For all genotypes, the vitamin $\mathrm{C}$ content in the skin was about $28 \%$ higher than that in the flesh, both at harvest and after storage (Table 5). Higher vitamin $\mathrm{C}$ contents in the skin have also been reported by Belous et al. (2014) for feijoa produced in Russia. These

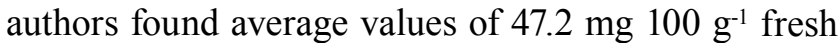
weight in the skin and $37.1 \mathrm{mg} 100 \mathrm{~g}^{-1}$ fresh weight in the flesh. The fruits of 'Alcântara' had the highest vitamin $C$ contents at harvest (101.0 and $92.5 \mathrm{mg} 100$ $\mathrm{g}^{-1}$ fresh weight in the skin and flesh, respectively) and

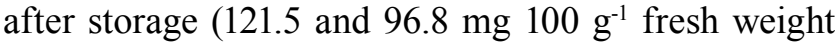
in the skin and flesh, respectively). At harvest, the vitamin $\mathrm{C}$ contents in the skin and flesh of 'Alcântara' fruits were 37.1 and $58.1 \%$ higher, respectively, when 
compared with 'Helena', which had the lowest vitamin C contents.

The vitamin $\mathrm{C}$ contents for the flesh of the five genotypes studied are higher than those reported by other authors for feijoa fruits produced in: Russia, of

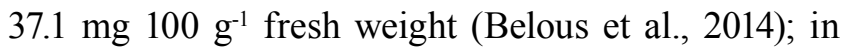

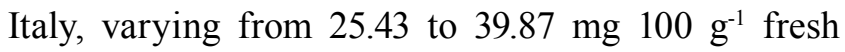
weight, depending on the genotype (Pasquariello et al., 2015); in Spain, of $26.9 \mathrm{mg} 100 \mathrm{~g} \mathrm{~g}^{-1}$ fresh weight (Romero-Rodriguez et al., 1994); and in Colombia, of

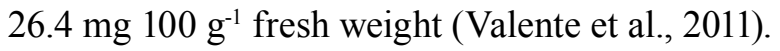

The vitamin C contents in the flesh of the fruits of the evaluated feijoa genotypes are higher than those found for mango (Mangifera indica L.) (17.5 mg $100 \mathrm{~g} \mathrm{~g}^{-1}$ fresh weight) and tangerine (Citrus reticulata Blanco) (21.5-32.5 mg $100 \mathrm{~g}^{-1}$ fresh weight), but similar or slightly lower than those for other types of fruits, such as orange (Citrus sinensis Pers.) (64.6-84.0 mg $100 \mathrm{~g} \mathrm{~g}^{-1}$ fresh weight), guava (Psidium guajava L.) (85.9 mg 100 $\mathrm{g}^{-1}$ fresh weight), and papaya (Carica papaya L.) $(80.2$ $\mathrm{mg} 100 \mathrm{~g}^{-1}$ fresh weight) (Couto \& Canniatti-Brazaca, 2010; Oliveira et al., 2011). This shows that feijoa fruit

Table 4. Color of the skin (external epidermis and internal parenchyma) and flesh tissues of fruits of different genotypes of feijoa (Acca sellowiana) at harvest and after 21 days of cold storage $\left(4 \pm 1^{\circ} \mathrm{C}\right.$ and $\left.90 \pm 5 \% \mathrm{RH}\right)$, followed by two days at ambient temperature $\left(23 \pm 2^{\circ} \mathrm{C} \text { and } 75 \pm 5 \% \mathrm{RH}\right)^{(1)}$.

\begin{tabular}{|c|c|c|c|c|c|c|}
\hline \multirow[t]{2}{*}{ Genotype } & \multicolumn{3}{|c|}{ At harvest } & \multicolumn{3}{|c|}{ After storage } \\
\hline & $\begin{array}{l}\text { External } \\
\text { epidermis }\end{array}$ & $\begin{array}{c}\text { Internal } \\
\text { parenchyma }\end{array}$ & Flesh & $\begin{array}{l}\text { External } \\
\text { epidermis }\end{array}$ & $\begin{array}{c}\text { Internal } \\
\text { parenchyma }\end{array}$ & Flesh \\
\hline & \multicolumn{6}{|c|}{ Lightness (L) } \\
\hline Alcântara & $45.6 \mathrm{aA}$ & $65.0 \mathrm{aA}$ & $46.1 \mathrm{bA}$ & 43.8abB & $59.5 \mathrm{aB}$ & $44.3 \mathrm{bcA}$ \\
\hline Helena & $45.0 \mathrm{aA}$ & $61.8 \mathrm{abA}$ & $54.8 \mathrm{aA}$ & $43.4 \mathrm{abB}$ & $60.0 \mathrm{aA}$ & $53.3 \mathrm{aA}$ \\
\hline Mattos & $44.7 \mathrm{aA}$ & $60.5 \mathrm{bcA}$ & $50.5 \mathrm{abA}$ & $42.6 \mathrm{bB}$ & $56.8 \mathrm{abA}$ & $42.3 \mathrm{cB}$ \\
\hline Nonante & $46.8 \mathrm{aA}$ & $61.6 \mathrm{bcA}$ & $50.1 \mathrm{abA}$ & $45.0 \mathrm{aA}$ & $54.8 \mathrm{bB}$ & $48.4 \mathrm{abA}$ \\
\hline Accession 2316 & $44.9 \mathrm{aA}$ & $58.5 \mathrm{cA}$ & $52.0 \mathrm{aA}$ & $44.2 \mathrm{abA}$ & $56.6 \mathrm{abA}$ & $49.0 \mathrm{abB}$ \\
\hline Mean & $45.4 \mathrm{~A}$ & $61.5 \mathrm{~A}$ & $50.7 \mathrm{~A}$ & $43.8 \mathrm{~B}$ & $57.5 \mathrm{~B}$ & $50.7 \mathrm{~B}$ \\
\hline \multirow[t]{2}{*}{ CV (\%) } & 2.9 & 4.3 & 7.9 & 3.0 & 5.1 & 9.7 \\
\hline & \multicolumn{6}{|c|}{ Chroma (C) } \\
\hline Alcântara & $21.5 \mathrm{abA}$ & $20.8 \mathrm{bB}$ & $9.3 \mathrm{cB}$ & $21.1 \mathrm{aA}$ & $22.5 \mathrm{~A}$ & $11.3 \mathrm{cA}$ \\
\hline Helena & $20.6 \mathrm{bA}$ & $22.7 \mathrm{abA}$ & $12.5 \mathrm{bA}$ & $19.3 \mathrm{aB}$ & $22.7 \mathrm{~A}$ & 13.6abA \\
\hline Mattos & $20.5 \mathrm{bA}$ & $22.7 \mathrm{abA}$ & $12.4 \mathrm{bA}$ & $19.6 \mathrm{aA}$ & $30.9 \mathrm{~A}$ & $12.9 \mathrm{bA}$ \\
\hline Nonante & $23.6 \mathrm{aA}$ & $23.5 \mathrm{aA}$ & $13.2 \mathrm{bA}$ & $21.2 \mathrm{aA}$ & $22.6 \mathrm{~A}$ & $14.2 \mathrm{abA}$ \\
\hline Accession 2316 & 21.3abA & $20.9 \mathrm{bB}$ & $15.5 \mathrm{aA}$ & $20.8 \mathrm{aA}$ & $22.6 \mathrm{~A}$ & $14.7 \mathrm{aA}$ \\
\hline Mean & $21.5 \mathrm{~A}$ & $22.1 \mathrm{~B}$ & $12.6 \mathrm{~B}$ & $20.4 \mathrm{~B}$ & $24.3 \mathrm{~A}$ & $13.3 \mathrm{~A}$ \\
\hline \multirow[t]{2}{*}{ CV (\%) } & 8.6 & 6.9 & 17.2 & 6.3 & 27.6 & 10.4 \\
\hline & \multicolumn{6}{|c|}{ Hue angle $\left(\mathrm{h}^{\circ}\right)$} \\
\hline Alcântara & $124.5 \mathrm{aA}$ & $87.7 \mathrm{bA}$ & $88.7 \mathrm{bA}$ & $123.9 \mathrm{aA}$ & $85.2 \mathrm{abB}$ & $84.4 \mathrm{bB}$ \\
\hline Helena & $124.2 \mathrm{aA}$ & $93.6 \mathrm{aA}$ & $93.1 \mathrm{aA}$ & $124.5 \mathrm{aA}$ & $90.3 \mathrm{aA}$ & $98.1 \mathrm{aB}$ \\
\hline Mattos & $125.6 \mathrm{aA}$ & $88.6 \mathrm{bA}$ & $91.5 \mathrm{abA}$ & $123.4 \mathrm{abB}$ & 86.6abA & $85.6 \mathrm{bB}$ \\
\hline Nonante & $120.6 \mathrm{bA}$ & $87.5 \mathrm{bA}$ & $91.0 \mathrm{abA}$ & $121.5 \mathrm{bA}$ & $83.4 \mathrm{bB}$ & $89.9 \mathrm{aA}$ \\
\hline Accession 2316 & $123.9 \mathrm{aA}$ & $88.4 \mathrm{bA}$ & $88.7 \mathrm{bA}$ & 123.1abA & 87.6abA & $86.6 \mathrm{abA}$ \\
\hline Mean & $123.8 \mathrm{~A}$ & $89.2 \mathrm{~A}$ & $90.6 \mathrm{~A}$ & $123.3 \mathrm{~A}$ & $86.6 \mathrm{~B}$ & 87.1B \\
\hline CV (\%) & 1.6 & 3.1 & 2.9 & 1.2 & 4.6 & 3.6 \\
\hline
\end{tabular}

${ }^{(1)}$ Means followed by equal letters, lowercase in the columns comparing genotypes and uppercase in the lines comparing harvest and cold storage evaluations for the same fruit tissue, do not differ by Tukey's test, at 5\% probability. Values are the mean of three years (2012, 2013, and 2014). RH, relative humidity. $\mathrm{CV}$, coefficient of variation. 
is a rich source of vitamin $\mathrm{C}$. The recommended daily intake (RDI) of vitamin C, established by the Food and Nutrition Board of Institute of Medicine of National Academy of Sciences (United States, 2000), are 75 and $90 \mathrm{mg}$ per day for women and men above 19 years of age, respectively. In Brazil, the RDI for adults is $45 \mathrm{mg}$ per day (Anvisa, 2005); therefore, the daily intake of $100 \mathrm{~g}$ feijoa (skin or flesh) would meet the RDI.

The vitamin $\mathrm{C}$ contents increased after refrigerated storage, from 77.3 to $99.6 \mathrm{mg} 100 \mathrm{~g}^{-1}$ fresh weight in the skin (22.4\% increase) and from 55.2 to 72.7 mg $100 \mathrm{~g}^{-1}$ fresh weight in the flesh $(24.1 \%$ increase) (Table 5). In most fruits and vegetables, a substantial loss in vitamin $\mathrm{C}$ is common during storage due to the enzymatic oxidation of ascorbic acid, particularly through the action of ascorbate oxidase (Lee \& Kader, 2000). However, for some crops, studies show an increase in the vitamin $\mathrm{C}$ content at postharvest. Antunes et al. (2003) found an increase in the vitamin C content in blackberry (Rubus spp.) stored until six days at $20^{\circ} \mathrm{C}$. The same behavior was verified by Mélo et al. (2000) for pitanga (Eugenia uniflora L.) stored under refrigeration at $8^{\circ} \mathrm{C}$. In both cases, the increase in vitamin $\mathrm{C}$ contents was attributed to the water loss of fruits during storage. However, in the present

Table 5. Vitamin C contents of the skin and flesh tissues of fruits of different genotypes of feijoa (Acca sellowiana) at harvest and after 21 days of cold storage $\left(4 \pm 1^{\circ} \mathrm{C}\right.$ and $90 \pm 5 \%$ $\mathrm{RH})$, followed by two days at ambient temperature $\left(23 \pm 2^{\circ} \mathrm{C}\right.$ and $75 \pm 5 \% \mathrm{RH})^{(1)}$.

\begin{tabular}{lccccc}
\hline Genotype & \multicolumn{2}{c}{ Skin } & & \multicolumn{2}{c}{ Flesh } \\
\cline { 2 - 3 } \cline { 5 - 6 } & At harvest & $\begin{array}{c}\text { After } \\
\text { storage }\end{array}$ & & At harvest & $\begin{array}{c}\text { After } \\
\text { storage }\end{array}$ \\
\hline \multirow{2}{*}{ Alcântara } & $101.0 \mathrm{aB}$ & $121.5 \mathrm{aA}$ & & $92.5 \mathrm{aB}$ & $96.8 \mathrm{aA}$ \\
Helena & $63.5 \mathrm{~dB}$ & $90.0 \mathrm{cA}$ & & $38.7 \mathrm{eB}$ & $49.5 \mathrm{eA}$ \\
Mattos & $82.0 \mathrm{bB}$ & $97.0 \mathrm{bA}$ & & $56.3 \mathrm{bB}$ & $80.8 \mathrm{bA}$ \\
Nonante & $64.0 \mathrm{~dB}$ & $90.7 \mathrm{cA}$ & & $41.1 \mathrm{~dB}$ & $58.1 \mathrm{dA}$ \\
Accession 2316 & $75.8 \mathrm{cB}$ & $98.8 \mathrm{bA}$ & & $47.1 \mathrm{cB}$ & $78.4 \mathrm{cA}$ \\
\hline Mean & $77.3 \mathrm{~B}$ & $99.6 \mathrm{~A}$ & & $55.2 \mathrm{~B}$ & $72.7 \mathrm{~A}$ \\
CV (\%) & 18.2 & 11.7 & & 36.0 & 23.6 \\
\hline
\end{tabular}

(1) Means followed by equal letters, lowercase in the columns comparing genotypes and uppercase in the lines comparing harvest and cold storage evaluations for the same fruit tissue, do not differ by Tukey's test, at 5\% probability. Values are the mean of two years (2013 and 2014). RH, relative humidity. $\mathrm{CV}$, coefficient of variation. study, the fresh mass loss does not entirely explain the increase in vitamin $\mathrm{C}$ in feijoa fruits (Table 1).

An increase in vitamin $\mathrm{C}$ contents was also observed in 'Alcântara' fruits subjected to low storage temperature $\left(4 \pm 1^{\circ} \mathrm{C}\right)$, followed by exposure to ambient conditions $\left(23 \pm 2^{\circ} \mathrm{C}\right)$ (Figure 1). At harvest, the vitamin $\mathrm{C}$ contents of the flesh and skin of the fruits of this cultivar were 93.6 and $102.6 \mathrm{mg} 100 \mathrm{~g}^{-1}$ fresh weight, respectively. Compared with these values, the vitamin $\mathrm{C}$ contents slightly increased in the flesh and skin at time zero at ambient temperature, after removal from refrigerated storage ( 21 days). It should be pointed out that the vitamin $\mathrm{C}$ contents, both in the skin and flesh, had a substantial increase, followed by a decrease, when kept at ambient temperature after removal from refrigerated storage. The vitamin $\mathrm{C}$ contents reached maximum values of $97.08 \mathrm{mg} 100 \mathrm{~g}^{-1}$ fresh weight in the flesh after 33 hours and of $122.04 \mathrm{mg}^{100 \mathrm{~g}^{-1}}$

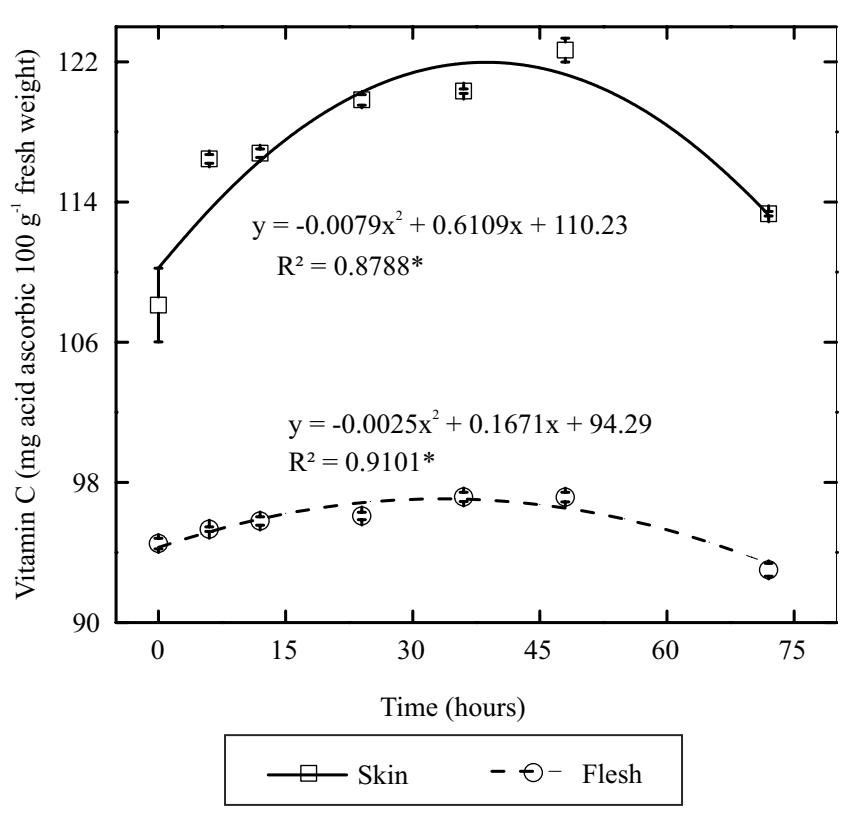

Figure 1. Vitamin $\mathrm{C}$ contents of the skin and flesh tissues of fruits of the 'Alcântara' genotype of feijoa (Acca sellowiana) after 21 days of cold storage $\left(4 \pm 1^{\circ} \mathrm{C}\right.$ and $90 \pm 5 \%$ $\mathrm{RH}$ ), followed by different times (in hours) at ambient temperature $\left(23 \pm 2^{\circ} \mathrm{C}\right.$ and $\left.75 \pm 5 \% \mathrm{RH}\right)$. Vertical bars represent the standard deviation of the mean. *Adjusted quadratic models are significant at $5 \%$ probability. At harvest, in 2014, the vitamin C contents of the flesh and skin tissues were 93.6 and $102.6 \mathrm{mg}$ ascorbic acid per $100 \mathrm{~g}^{-1}$ fresh weight, respectively. 
fresh weight in the skin after 39 hours under ambient conditions.

In plants, vitamin $\mathrm{C}$ production occurs via the rapid conversion of L-galactono-1,4-lactone (GAL) into L-ascorbic acid by the enzyme GAL dehydrogenase (Locato et al., 2013). The enzymatic activity of GAL dehydrogenase increases under low-temperature storage (Smirnoff \& Wheeler, 2000). This could explain, in the case of feijoa, the increase in vitamin $\mathrm{C}$ observed during refrigerated storage, particularly when followed by exposure to ambient temperatures, as a defense mechanism to protect the fruit tissues from chilling injury. It is also important to note that vitamin $\mathrm{C}$ is more stable in an acid medium (Lee $\&$ Kader, 2000). Therefore, the maintenance of the vitamin $\mathrm{C}$ content in feijoa could have been favored by the low $\mathrm{pH}$ values of the fruits (Table 2).

The feijoa fruits showed a short postharvest life due to the occurrence of physicochemical changes, which led to flesh darkening and losses in quality-related attributes, such as texture, taste, and aroma (Tables 2, 3, and 4). However, the feijoa genotypes differed regarding the postharvest preservation of quality attributes. For all genotypes, the vitamin $\mathrm{C}$ content in the skin was higher $(\sim 28 \%)$ than that in the flesh, and increased in both tissues after refrigerated storage, i.e., by $22.4 \%$ in the skin and $24.1 \%$ in the flesh (Table 5). Since the skin is a portion of the feijoa fruit which is not traditionally consumed, further studies are required to determine the presence of other minerals and functional compounds in it, as well as to develop technologies to facilitate its use in food products.

\section{Conclusions}

1. Feijoa (Acca sellowiana) fruits exhibit flesh darkening and a rapid reduction in titratable acidity and loss in texture during cold storage at $4 \pm 1^{\circ} \mathrm{C}$ for 21 days, followed by exposure to ambient temperature of $23 \pm 2^{\circ} \mathrm{C}$ for two days.

2. Fruits of the Nonante and Mattos cultivars show better preservation of texture, and fruits of Nonante exhibit less flesh darkening during storage, with higher postharvest potential.

3. The vitamin $\mathrm{C}$ content in the skin is higher than that in the flesh of feijoa fruits, and, during cold storage, vitamin $\mathrm{C}$ contents increase in both tissues.
4. The highest vitamin $\mathrm{C}$ contents are found in the skin and flesh tissues of the fruits of the Alcântara cultivar.

\section{Acknowledgments}

To Conselho Nacional de Desenvolvimento Científico e Tecnológico (CNPq), for financial support; and to the experimental station of São Joaquim of Empresa de Pesquisa Agropecuária e Extensão Rural de Santa Catarina (Epagri), for supplying the feijoa fruits.

\section{References}

AMARANTE, C.V.T. do; STEFFENS, C.A.; BENINCÁ, T.D.T.; HACKBARTH, C.; SANTOS, K.L. dos. Qualidade e potencial de conservação pós-colheita dos frutos em cultivares brasileiras de goiabeira-serrana. Revista Brasileira de Fruticultura, v.35, p.990-999, 2013. DOI: 10.1590/S0100-29452013000400009.

AMARANTE, C.V.T. do; STEFFENS, C.A.; DUCROQUET, J.P.H.J.; SASSO, A. Qualidade de goiaba-serrana em resposta à temperatura de armazenamento e ao tratamento com 1-metilciclopropeno. Pesquisa Agropecuária Brasileira, v.43, p.1683-1689, 2008. DOI: 10.1590/S0100-204X2008001200007.

ANTUNES, L.E.C.; DUARTE FILHO, J.; SOUZA, C.M. de. Conservação pós-colheita de frutos de amoreira-preta. Pesquisa Agropecuária Brasileira, v.38, p.413-419, 2003. DOI: 10.1590/ S0100-204X2003000300011.

ANVISA. Agência Nacional de Vigilância Sanitária. Resolução RDC n ${ }^{\circ} 269$, de 22 de setembro de 2005. [Aprova o regulamento técnico sobre a ingestão diária recomendada (IDR) de proteína, vitaminas e minerais]. Diário Oficial da União, 23 set. 2005. Seção 1, p.372.

BEloUS, O.; OMAROV, M.; OMAROVA, Z. Chemical composition of fruits of a feijoa ( $F$. sellowiana) in the conditions of subtropics of Russia. Potravinarstvo Scientific Journal for Food Industry, v.8, p.119-123, 2014. DOI: 10.5219/358.

BONTEMPO, P.; MITA, L.; MICELI, M.; DOTO, A.; NEBBIOSO, A.; DE BELLIS, F.; CONTE, M.; MINICHIELLO, A.; MANZO, F.; CARAFA, V.; BASILE, A.; RIGANO, D.; SORBO, S.; COBIANCHI, R.C.; SCHIAVONE, E.M.; FERRARA, F.; DE SIMONE, M.; VIETRI, M.T.; CIOFFI, M.; SICA, V.; BRESCIANI, F.; LERA, A.R. de; ALTUCCI, L.; MOLINARI, A.M. Feijoa sellowiana derived natural flavone exerts anti-cancer action displaying HDAC inhibitory activities. International Journal of Biochemistry and Cell Biology, v.39, p.1902-1914, 2007. DOI: 10.1016/j.biocel.2007.05.010.

COUTO, M.A.L.; CANNIATTI-BRAZACA, S.G. Quantificação de vitamina $\mathrm{C}$ e capacidade antioxidante de variedades cítricas. Ciência e Tecnologia de Alimentos, v.30, p.15-19, 2010. Suplemento 1. DOI: 10.1590/S0101-20612010000500003. 
EL-SHENAWI, S.M.; MARZOUK, M.S.; EL DIB, R.A.; ELYAZED, H.E.A.; SHAFFIE, N.M.; MOHARRAM, F.A. Polyphenols and biological activities of Feijoa sellowiana leaves and twigs. Revista Latinoamericana de Química, v.36, p.103$120,2008$.

KARAMI, M.; SAEIDNIA, S.; NOSRATI, A. Study of the hepatoprotective activity of methanolic extract of Feijoa sellowiana fruit against MDMA using the isolated rat liver perfusion system. Iranian Journal of Pharmaceutical Research, v.12, p.85-91, 2013.

LEE, S.K.; KADER, A.A. Preharvest and postharvest factors influencing vitamin $\mathrm{C}$ content of horticultural crops. Postharvest Biology and Technology, v.20, p.207-220, 2000. DOI: 10.1016/ S0925-5214(00)00133-2

LOCATO, V.; CIMINI, S.; DE GARA, L. Strategies to increase vitamin $C$ in plants: from plant defense perspective to food biofortification. Frontiers in Plant Science, v.4, p.1-12, 2013. DOI: $10.3389 /$ fpls.2013.00152.

MÉLO, E. de A.; LIMA, V.L.A.G. de; NASCIMENTO, P.P. do. Temperatura no armazenamento de pitanga. Scientia Agricola, v.57, p.629-634, 2000. DOI: 10.1590/S0103-90162000000400006.

MONFORTE, M.T.; LANUZZA, F.; MONDELLO, F.; NACCARI, C.; PERGOLIZZI, S.; GALATI, E.M. Phytochemical composition and gastroprotective effect of Feijoa sellowiana Berg fruits from Sicily. Journal of Coastal Life Medicine, v.2, p.14-21, 2014. DOI: 10.12980/JCLM.2.2014J12.

MORETTO, S.P.; NODARI, E.S.; NODARI, R.O. A introdução e os usos da feijoa ou goiabeira serrana (Acca sellowiana): a perspectiva da história ambiental. Fronteiras: Journal of Social, Technological and Environmental Science, v.3, p.67-79, 2014.

OLIVEIRA, D. da S.; AQUINO, P.P.; RIBEIRO, S.M.R.; PROENÇA, R.P. da C.; PINHEIRO-SANT'ANA, H.M. Vitamina $\mathrm{C}$, carotenoides, fenólicos totais e atividade antioxidante de goiaba, manga e mamão procedentes da Ceasa do Estado de Minas Gerais. Acta Scientiarum. Health Sciences, v.33, p.8998, 2011. DOI: 10.4025/actascihealthsci.v33i1.8052.

ÖMER, B.; ELMASTAS, M.; GEDIKLI, F. Total phenolic compounds and antioxidant capacity of leaf, dry fruit and fresh fruit of feijoa (Acca sellowiana, Myrtaceae). Journal of Medicinal Plants Research, v.4, p.1065-1072, 2010.

PASQUARIELLO, M.S.; MASTROBUONI, F.; DI PATRE, D.; ZAMPELLA, L.; CAPUANO, L.R.; SCORTICHINI, M.; PETRICCIONE, M. Agronomic, nutraceutical and molecular variability of feijoa (Acca sellowiana) (O. Berg) germplasm. Scientia Horticulturae, v.191, p.1-9, 2015. DOI: 10.1016/j. scienta.2015.04.036.

RODRÍGUEZ, M.; ARJONA, H.E.; GALVIS, J.A. Maduración del fruto de feijoa (Acca sellowiana Berg) em los clones 41
(Quimba) y 8-4 a temperatura ambiente en condiciones de la Sabana de Bogotá. Agronomía Colombiana, v.24, p.68-76, 2006.

ROMERO-RODRIGUEZ, M.A.; VAZQUEZ-ODERIZ, M.L.; LOPEZ-HERNANDEZ, J.; SIMAL-LOZANO, J. Composition of babaco, feijoa, passion-fruit and tamarillo produced in Galicia (NW Spain). Food Chemistry, v.49, p.251-255, 1994. DOI: 10.1016/0308-8146(94)90168-6.

ROSSI, A.; RIGANO, D.; PERGOLA, C.; FORMISANO, C.; BASILE, A.; BRAMANTI, P.; SENATORE, F.; SAUTEBIN, L. Inhibition of inducible nitric oxide synthase expression by an acetonic extract from Feijoa sellowiana Berg. fruits. Journal of Agricultural and Food Chemistry, v.55, p.5053-5061, 2007. DOI: $10.1021 /$ jf070510d.

RUPAVATHARAM, S.; EAST, A.R.; HEYES, J.A. Re-evaluation of harvest timing in 'Unique' feijoa using 1-MCP and exogenous ethylene treatments. Postharvest Biology and Technology, v.99, p.152-159, 2015. DOI: 10.1016/j.postharvbio.2014.08.011.

SANTOS, K.L. dos; DUCROQUET, J.P.H.J.; NAVA, G.; AMARANTE, C.V.T. do; SOUZA, S.N. de; PERONI, N.; GUERRA, M.P.; NODARI, R.O. (Org.). Orientações para o cultivo da goiabeira-serrana (Acca sellowiana). Florianópolis: Epagri, 2011. 44p. (Epagri. Boletim Técnico, 153).

SCHOTSMANS, W.C.; EAST, A.; THORP, G.; WOOLF, A.B. Feijoa (Acca sellowiana [Berg.] Burret). In: YAHIA, E.M. (Ed.). Postharvest biology and technology of tropical and subtropical fruits: cocona to mango. Cambridge: Woodhead Publishing, 2011. v.3, p.115-133.

SMIRNOFF, N.; WHEELER, G.L. Ascorbic acid in plants: biosynthesis and function. Critical Reviews in Biochemistry and Molecular Biology, v.35, p.291-314, 2000. DOI: $10.1080 / 10409230008984166$.

STROHECKER, R.; HENNING, H.M. Analisis de vitaminas: métodos comprobados. Madrid: Paz Montolvo, 1967. 428p.

UNITED STATES. Institute of Medicine. Dietary reference intakes for vitamin $C$, vitamin $E$, selenium and carotenoids. Washington: National Academy Press, 2000. 529p. DOI: $10.17226 / 9810$.

VALENTE, A.; ALBUQUERQUE, T.G.; SANCHES-SILVA, A.; COSTA, H.S. Ascorbic acid content in exotic fruits: a contribution to produce quality data for food composition databases. Food Research International, v.44, p.2237-2242, 2011. DOI: 10.1016/j. foodres.2011.02.012

VELHO, A.C.; AMARANTE, C.V.T. do; ARGENTA, L.C.; STEFFENS, C.A. Influência da temperatura de armazenamento na qualidade pós-colheita de goiabas serranas. Revista Brasileira de Fruticultura, v.33, p.14-20, 2011. DOI: 10.1590/S010029452011005000016.

Received on January 7, 2016 and accepted on February 20, 2017

Pesq. agropec. bras., Brasília, v.52, n.9, p.734-742, set. 2017

DOI: 10.1590/S0100-204X2017000900005 